\title{
BETA THALASSAEMIA IN CYPRUS
}

MAJOR C. M. BATE, M.B., Ch.B., M.R.C.P., R.A.M.C.

MAJOR G. HUMPHRIES, M.A., B.M., B.Ch., D.T.M.\&H., M.R.C.Path, R.A.M.C.

Queen Elizabeth Military Hospital, Woolwich

Mr. M. C. K. TWEEDIE

Statistician, Liverpool University

SUMMARY: An account is given of a survey for B-thalassaemia trait among $\mathbf{4 2 8}$ Greek Cypriots and 87 Turkish Cypriots. Their respective gene frequencies were found to be 16.8 per cent and 18.4 per cent.

Five per cent carried the $\alpha$-thalassaemia ${ }_{1}$ trait and five per cent were iron deficient. One case of heterozygosity for Hb Lepore was found. Criteria for diagnosis of the carrier state are discussed.

\section{Introduction}

During a four year period of military service in Cyprus, two of the authors (Majors C. M. Bate and G. Humphries) were struck by the magnitude of the problem of thalassaemia in the community, and its social and economic implications.

One child's treatment for a year requires 24 hospital visits, at least, 12 units of blood and about $£ 1,100$ for chelating agents.

Seven surveys have been carried out since 1946 to establish the incidence of the B-thalassaemia trait in Cyprus. All have suffered from drawbacks to a greater or lesser extent, and have returned results varying from five to fifty per cent. Only one

\section{Table I}

Published surveys for thalassaemia trait in Cyprus

\begin{tabular}{|l|c|c|c|}
\hline \multicolumn{1}{|c|}{ Author } & Year & \multicolumn{2}{|c|}{ Percentage carrier rate } \\
\cline { 2 - 3 } & & Greek & Turkish \\
\hline Fawdrey (1944) & 1944 & 17 & 21 \\
\hline Banton (1951) & 1951 & 28 & - \\
\hline Plato et al (1964) & 1964 & 50 & - \\
\hline $\begin{array}{l}\text { World Health Organisation } \\
\text { (1966) }\end{array}$ & 1966 & 5 & - \\
\hline Kattamis et al (1972) & 1972 & 5 & see text \\
\hline Modell et al (1972) & 1972 & 17.3 & \\
\hline Ashiotis et al (1973) & 1973 & 14 & - \\
\hline
\end{tabular}

measured the incidence in Turkish Cypriots. Table I summarises these results. The present study was undertaken to clarify the situation in both communities. 


\section{Subjects and methods}

To obtain a sample of the Cypriot population unbiased by racial group or town of origin, 515 Cypriot civilians employed by the British Army in the Eastern Sovereign Base Area of Dhekelia were studied. Eighty-seven (17 per cent) were Turkish, a figure corresponding closely to the ratio in the general population. They came from villages in all parts of Cyprus and their ages ranged from 17 to over 60 years. All had passed a medical examination before being accepted for employment and were in apparent good health. Sixty-five were women.

A control group of known thalassaemia heterozygotes was provided by 84 parents of children with homozygous B-thalassaemia attending the clinic at the British Military Hospital at Dhekelia.

Patients admitted to the survey were visited at their places of work and bled. The samples were then taken to the pathology laboratory of the British Military Hospital, where a blood film was immediately prepared and haemoglobin concentration, mean corpuscular haemoglobin concentration, packed cell volume estimation and serum iron concentrations were determined by standard techniques. The amount of haemoglobin $\mathrm{A}_{2}\left(\mathrm{Hb} \mathrm{A}_{2}\right)$ present was determined by cellulose acetate electrophoresis in a tris/barbital buffer system (Graham and Grunbaum 1963), followed by elution of the $A_{2}$ band and its spectrophotometric quantitation as a percentage of the total haemoglobin present.

The amount of haemoglobin $\mathrm{F}$ ( $\mathrm{Hb} \mathrm{F}$ ) present was determined by the method of Betke, Marti and Schlicht (1959).

All the peripheral films were examined without prior knowledge of the amounts of haemoglobins $\mathrm{F}$ and $\mathrm{A}_{2}$ present. Electronic red cell counting was not available to the authors, nor to civilian laboratories in Cyprus.

\section{Results}

The $\mathrm{Hb} \mathrm{A_{2 }}$ and $\mathrm{Hb} \mathrm{F}$ survey values are plotted in Figures 1 and 2. The $\mathrm{Hb} \mathrm{A}_{2}$ histogram shows a unimodal distribution, with a definite skew to the right, ranging from 0.8 per cent to 9.1 per cent. A bimodal curve with a distinct discriminatory gap was expected for a mixed normal and carrier population.

The corresponding histograms for the parental group are shown in Figures 3 and 4. The $\mathrm{Hb} \mathrm{A}_{2}$ histogram shows a symmetrical distribution ranging from $2.9 \mathrm{per}$ cent to 7.5 per cent with a mean of 4.9 per cent.

A preliminary statistical analysis of the $\mathrm{Hb} \mathrm{A}_{2}$ data (assuming that all members of the parental group carried the trait) was made by the method of moments. The first four cumulants of the observed distribution in the survey groups were used and no allowance was made for the effect of sampling variation in computing the divisors for the sums of powers. These calculations gave the following results:

Percentage with trait 18.5: Mean of trait $\mathrm{Hb} \mathrm{A}_{2}^{\prime} 4.96$ per cent: Standard deviation of trait $\mathrm{Hb} \mathrm{\textrm {A } _ { 2 }} 0.798$.

Mean of non trait $\mathrm{Hb} \mathrm{A}_{2} 2.59$ per cent: Standard deviation of non trait $\mathrm{Hb} \mathrm{A}_{2}$ 0.555 .

$\mathrm{Hb} \mathrm{A} \mathrm{A}_{2}$ value for an even chance 3.9 per cent. 




Fig. 1. Survey $\mathrm{Hb} \mathrm{A}_{2}$ values






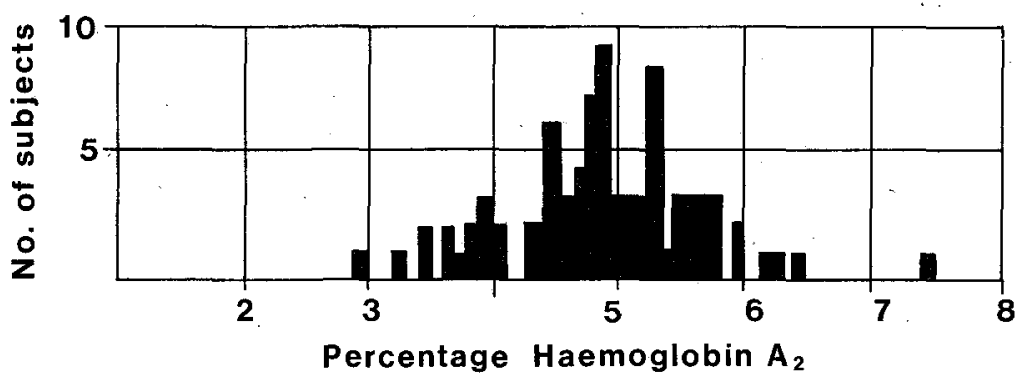

Fig. 3. $\mathrm{Hb} \mathrm{A}_{2}$ values in known heterozygotes



Fig. 4. Hb F values in known heterozygotes

Curves were plotted of the estimates of the separate components and their combination, and also of the estimated probability that a person with a specified level of $\mathrm{Hb} \mathrm{A}_{2}$ has the trait (Fig. 5). The probability curve shows that there is an area in which sole reliance on $\mathrm{Hb} \mathrm{A}_{2}$ values fails to separate carriers from normals.

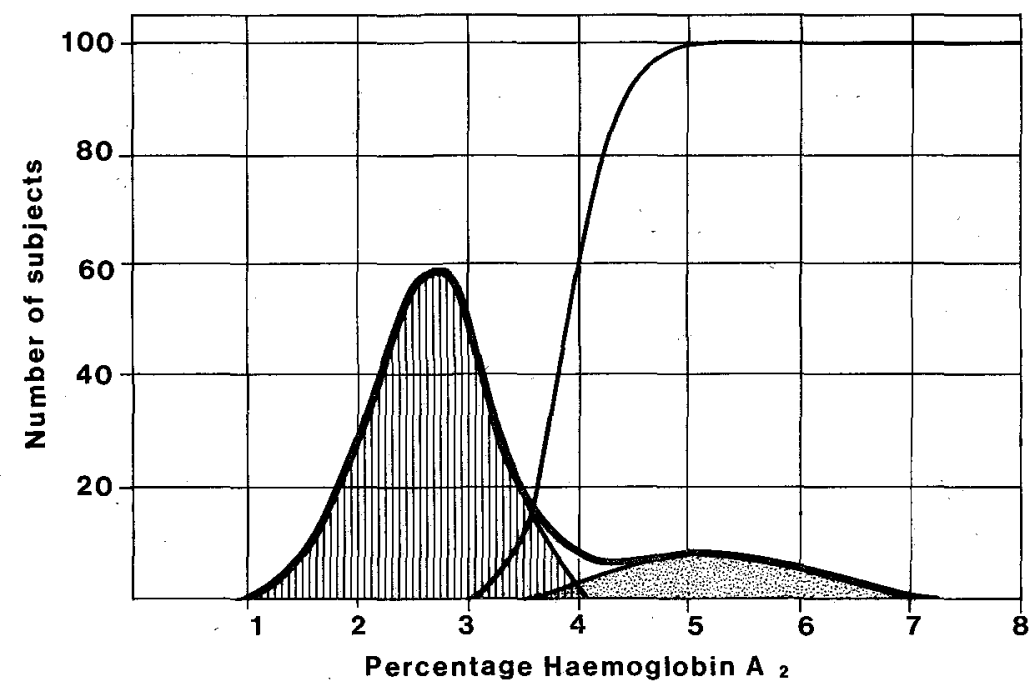

Fig. 5. Hb $\mathrm{A}_{2}$ distributions in normal and carried populations with computed probability curve 
In an attempt to overcome this problem all the survey data were re-examined in conjunction with the analysis of the $\mathrm{Hb} \mathrm{A}_{2}$ figures given above, taking into account haemoglobin levels, absolute indices, serum iron levels, haemoglobin electrophoresis, $\mathrm{Hb} \mathrm{F}$ values and family and personal histories. A number of different categories emerged.

a. If the $\mathrm{Hb} \mathrm{A_{2 }}$ level was 4.1 per cent or over, the subject was regarded as having 3 -thalassaemia trait (the probability curve shows that 4.1 per cent $\mathrm{Hb} \mathrm{A}_{2}$ represents a 77.5 per cent chance of carrier status). Seventy-six subjects were in this category.

b. A Hb A $\mathrm{A}_{2}$ level of between 2.5 per cent and 4.1 per cent ( 3.5 per cent corresponding to a 10 per cent chance of the trait on the probability curve) in association with strong corroborating evidence for the carrier state was considered to establish the diagnosis. Evidence accepted as corroboration included the presence of mild anaemia with film changes in the absence of iron deficiency, or a positive family history of thalassaemia. Only three subjects were in this category.

c. When the 515 measured values of $\mathrm{Hb} \mathrm{F}$ were plotted they formed the distribution curve shown in Figure 4. Nine Greek subjects not included in groups (a) and (b) above, had values which lay clearly to the right of the main histogram. They ranged from 2.4 per cent to 4.4 per cent with a mean of 3.5 per cent. These subjects were classified as suffering from heterozygous $\delta$ B-thalassaemia although it is not possible to exclude that variant of $\mathrm{B}$-thalassaemia trait with a high $\mathrm{Hb} F$ level.

d. Twenty-six subjects were iron deficient. It was accepted that some masked B-thalassaemia traits could be among this group.

e. Twenty-seven individuals showed mild film changes in the presence of normal $\mathrm{Hb} \mathrm{A}_{2}$ and $\mathrm{Hb} F$ levels, normal indices and iron studies. The commonest film changes were anisocytosis and poikilocytosis with target cells, but occasionally schistocytes were also seen. It was felt that these cases may be carriers for the more severe $\alpha$-thalassaemia ${ }_{1}$ gene. This would give a carrier rate of 5.2 per cent for the gene. Ashiotis et al (1973), when surveying cord bloods from 176 Cypriot neonates for haemoglobin Bart's, concluded that 6.3 per cent carried $\alpha$-thalassaemia ${ }_{1}$ trait and 5.2 per cent $\alpha$-thalassaemia ${ }_{2}$ trait.

f. One Greek man was found to be a carrier for haemoglobin Lepore. Hitherto this condition has been described only in Turkish Cypriots (Beavan 1964).

g. Finally, there was a group of 14 subjects with minimal non diagnostic haematological changes.

The results are summarised in Table II.

\section{Discussion}

Since the work of Kunkel and Wallenius (Kunkel et al 1955), it has been known that most individuals heterozygous for $\mathbf{B}$-thalassaemia have an elevated $\mathbf{H b}$ $\mathrm{A}_{2}$ level. Though some authors (Vella 1959, Weatherall 1964) have found a discriminatory gap between the $\mathrm{Hb} \mathrm{A}_{2}$ values in normals and carriers, others (Kunkell et al 1957, Gerald and Diamond 1958, Carcassi, Cepellini and Siniscalco 1957, Silvestroni, Bianco and Muzzolini 1957. Silvestroni, Bianco and Modiano 1957, 
Table II

Summary of results

\begin{tabular}{|l|c|c|c|c|c|c|}
\hline & \multicolumn{2}{|c|}{ Turkish } & \multicolumn{2}{|c|}{ Greek } & \multicolumn{2}{|c|}{ Total } \\
\cline { 2 - 6 } & No. & Percentage & No. & Percentage & No. & Percentage \\
\hline$\alpha$-thalassaemia ${ }_{1}$ & 5 & 5.7 & 22 & 5.1 & 27 & 5.2 \\
\hline Iron deficiency & 2 & 2.3 & 24 & 5.6 & 26 & 5.05 \\
\hline$\beta$-thalassaemia & 16 & 18.4 & 63 & 14.7 & 79 & 15.3 \\
\hline$\delta \beta$-thalassaemia & - & - & 9 & 2.1 & 9 & 1.7 \\
\hline$\beta+\delta \beta$-thalassaemia & 16 & 18.4 & 72 & 16.8 & 88 & 17.1 \\
\hline Number of subjects & 87 & 100 & 428 & 100 & 515 & 100 \\
\hline
\end{tabular}

Table III

Published values for $\mathrm{Hb}_{\mathbf{2}}$ in normal heterdzygotes

\begin{tabular}{|c|c|c|c|c|c|c|c|c|}
\hline \multirow[t]{2}{*}{ Authors } & \multicolumn{3}{|c|}{ Normals } & \multicolumn{3}{|c|}{ Heterozygotes } & \multirow{2}{*}{\begin{tabular}{|c|} 
Percentage \\
heterozygotes \\
in normal range
\end{tabular}} & \multirow[t]{2}{*}{ Comments } \\
\hline & No. & Mean & Range & No. & Mean & Range & & \\
\hline $\begin{array}{l}\text { Kunkel et } \\
\text { al (1957) }\end{array}$ & 65 & 2.54 & $1.8-3.2$ & 32 & 4.3 & $2.2-6.4$ & 6.3 & $\begin{array}{l}\text { Two cases de- } \\
\text { scribed as } \\
\text { thalassaemia } \\
\text { intermedia are } \\
\text { omitted }\end{array}$ \\
\hline $\begin{array}{l}\text { Gerald and } \\
\text { Diamond } \\
\text { (1958) }\end{array}$ & - & - & - & 23 & 4.7 & $3.3-6.8$ & 17.4 & $\begin{array}{l}\text { Four values } \\
\text { 3.3-3.8 are } \\
\text { much lower } \\
\text { than the re- } \\
\text { mainder, attri- } \\
\text { buted by the } \\
\text { authors to } \\
\text { genetic varia- } \\
\text { tion }\end{array}$ \\
\hline $\begin{array}{l}\text { Carcassi et } \\
\text { al (1957) }\end{array}$ & - & - & - & - & 5.2 & $1.1-7.8$ & NK & $\begin{array}{l}\text { Ten values } \\
\text { between } 1.2-2.5\end{array}$ \\
\hline $\begin{array}{l}\text { Silvestroni } \\
\text { et al (1957) }\end{array}$ & 54 & 2.13 & - & 74 & 4.3 & - & NK & $\begin{array}{l}\text { Overlap stated } \\
\text { to be present } \\
\text { in Abnormal } \\
\text { Haemoglobin } \\
\text { Symposium } \\
1959\end{array}$ \\
\hline $\begin{array}{l}\text { Silvestroni } \\
\text { et al } \\
\text { (1957A) }\end{array}$ & 223 & 1.95 & $\rightarrow$ & 182 & 4.2 & $3.0-5.8$ & NK & \\
\hline $\begin{array}{l}\text { Josephson } \\
\text { et al (1958) }\end{array}$ & - & - & - & 27 & 6.2 & $3.9-9.2$ & NK & $\begin{array}{l}\text { Five cases with } \\
\text { Hb F values } \\
\text { above } 12.5 \text { per } \\
\text { cent omitted }\end{array}$ \\
\hline $\begin{array}{l}\text { Fessas } \\
(1959)\end{array}$ & 20 & 2.9 & $2.0-3.9$ & 52 & - & $3.4-12.1$ & 7.0 & \\
\hline Vella (1959) & 79 & 1.78 & $0-2.51$ & 9 & 4.08 & $2.67-5.56$ & 0 & \\
\hline $\begin{array}{l}\text { Weatherall } \\
\text { (1964) }\end{array}$ & - & - & & 94 & 5.16 & $3.4-7.4$ & 0 & \\
\hline
\end{tabular}


Josephson 1958, Fessas 1959) like the present authors, have failed to do so (Table III). There are several possible reasons for the difference. The first is genetic variation in the amount of $\mathrm{Hb} \mathrm{A}_{2}$ synthesised by heterozygotes. All individuals in any one family have similar $\mathrm{Hb} \mathrm{A}_{2}$ levels. A heterozygote within a family with very low levels may have a value in the normal range, even though elevated for that family. Secondly, co-existing disease, in particular iron deficiency, may suppress $\mathbf{H b} \mathbf{A}_{2}$

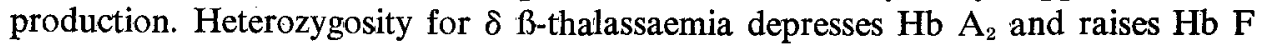
levels. The carrier state for $\mathrm{Hb}$ Lepore affects these levels similarly, but about 10 per cent of slowly migrating Lepore haemoglobin will be detected by electrophoresis at an alkaline $\mathrm{pH}$. Thirdly, spurious elevation of $\mathrm{Hb} \mathrm{A}_{2}$ may be found in macrocytic anaemias, particularly pernicious anaemia.

Finally, it is possible that electrophoretic methods of estimating $\mathrm{Hb} \mathrm{A}_{2}$ are not sufficiently precise.

\section{Previous surveys}

Fawdrey (1944) surveyed 532 Greek and Turkish school-children using a simplified osmotic fragility method which failed to distinguish iron deficiency and $\alpha$-thalassaemia.

Banton (1951) used Fawdrey's method and blood film examination in 100 Greek soldiers. He later surveyed 65 of the inhabitants of Alithinou village, selected because it contained known homozygous cases. Although certain relatives were excluded, this was a highly selected population.

Plato (1964) examined 478 Greek male school-children, electrophoresing blood from those with film abnormalities. He estimated $\mathrm{Hb} \mathrm{A}_{2}$ by visual inspection and a very low carrier rate was obtained.

The World Health Organisation Technical Report (1966) does not quote the source of its data.

Kattamis (1972) studied 158 Greek Cypriot National Guardsmen using red cell morphology, red cell counts, osmotic fragility, starch gel electrophoresis and $\mathrm{Hb} F$ and $\mathrm{Hb} \mathrm{A}_{2}$ estimations. He did not survey any women or Turks.

Modell et al (1972) using an indirect method of comparing the birth rate of cases in three London boroughs with the total birth rate of Cypriot children in these areas. The figures were corrected to include Turks and exclude Cypriot males marrying non-Cypriot females. The figures do not distinguish between Greek and Turkish cases, and rely on accuracy in record keeping and case detection.

Ashiotis (1973) surveyed 326 Greek Cypriot National Guardsmen. Blood

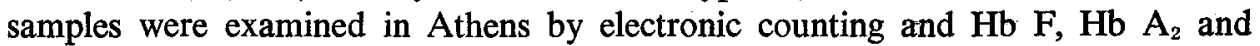
Bart's determined by standard techniques. Again the survey only included young Greek males. The State Hospital records were examined to detect cases of homozygous B-thalassaemia, and these were set against yearly birth rates in the Greek and Turkish communities. However, many cases are not diagnosed and not all are treated in State Hospitals. Blood bank and Central Nicosia Laboratory records showed that 30 to 35 per cent of cases did not appear in State records - Due to socio-political factors, the data for the Turkish community were less reliable. 
In 1970 it was estimated that 10,408 Greek children were born in Cyprus and of these 73 would be expected to be suffering from Cooley's anaemia. Turkish birth rate figures are not available, but in 1963 it was estimated that 2,639 Turkish children were born, of whom 22 would be expected to be thalassaemic, i.e. about 95 $B$-thalassaemic children are born every year in Cyprus.

To treat only these cases for one year would involve transfusing them with about 1,000 units of blood and the expenditure of nearly $£ 105,000$ for intramuscular chelating agents - a formidable problem for a population of only 633,000 .

One solution would be to reduce the frequency of homozygotes for Cooley's anaemia by discouraging mating between heterozygotes. It is not too difficult to envisage a screening programme aimed at detecting the carrier state in, for example, all school leavers. Those suffering from the trait could be informed of the fact and advised of the risks involved in marrying another carrier.

Detection of the carrier state is greatly simplified if electronic methods for measuring red cell counts and indices are available. Pearson et al (1974) found that measurement of the mean corpuscular volume (M.C.V.) was a reliable screening test for thalassaemia trait, $\alpha$ and 3 -heterozygotes having a M.C.V. of less than $79 \mu \mathrm{m}^{3}$. This cut-off point gave no false negative results and an acceptably low number of false positive results due to iron deficiency anaemia. Those positive on the screening tests were next subjected to a $\mathrm{Hb} \mathrm{\textrm {A } _ { 2 }}$ estimation, an elevated level confirming the diagnosis of thalassaemia trait. In the event of finding a normal or low haemoglobin $A_{2}$ the next step was the estimation of the serum iron. If this was low, iron treatment was instituted. Once the iron deficiency was successfully treated a repeat $\mathrm{Hb} \mathrm{A}_{2}$ within normal limits confirmed the diagnosis of simple iron deficiency, and an elevated $\mathrm{Hb} \mathrm{A}_{2}$ revealed the presence of $B$-thalassaemia trait masked by coexistent iron deficiency.

The combination of a low M.C.V. with a normal $\mathrm{Hb} \mathrm{A}_{2}$ level led to a tentative diagnosis of $\alpha$-thalassaemia trait and required family studies for final confirmation.

\section{REFERENCES}

Ashiotis, T. H. et al (1973). Brit. med. J. ii, 38.

Banton, A. H. (1951). Amer. J. hum. Genet. 3, 47.

BeAven, G. H. et al (1964). Brit. J. Haemat. 10, 159.

BetKe, K., MARTi, H. R. and Schlicht, I. (1959). Nature (Lond.) 184, 1877.

Carcassi, V., Ceepellini, R. and Siniscalco, M. (1957). Haematologica 42, 1635.

FAWDRY, A. L. (1944). Lancet i, 171.

Fessas, P. (1959). In Abnormal Haemoglobins. Ed. J. H. P. Jonxis and J. F. D. Delafresnaye. Blackwell Scientific Publications. Oxford. P. 134.

Gerald, P. S. and Diamond, K. L. (1958). Blood 13, 61.

Graham, J. L. and Grunbaum, B. W. (1963). Amer. J. clin. Path. 39, 567.

JoSEPHSON, A. M. et al (1958). Blood 13, 543:

Katramis, C. et al (1972). Brit. med. J. iii, 470.

KunKEL, H. G. and Wallenius, G. (1955). Science 122, 288.

KuNKEL, H. G. et al (1957). J. clin. Invest. 36, 1615.

Modell, C. B., Benson, A. and Payling Wright, C. R. (1972). Brit. med. J. iii, 737. 
Pearson, H. A. et al (1974). Ann. N.Y. Acad. Sci. 232, 135.

Plato, C. C., Rucknagel, D. L. and Gershowitz, H. (1964). Amer. J. hum. Genet. 16, 267.

Silvestroni, E., Bianco, I. and Muzzolini, M. (1957). Progr. Med. (Napoli) 13, 673.

Silvestroni, E., Bianco, I. and Modiano, G. (1957A). Progr. Med. (Napoli) 13, 772.

Vella, F. (1959). Med. J. Malaya, The XIV, 31.

Weatherall, D. J. (1964). Ann. N.Y. Acad. Sci. 119, 450.

World Health Organisation Technical Report (1966). Series 338, 36.

To the Army

Professor P. A. Dudgeon, M.C., T.D., D.L., M.A., M.D., F.R.C.P., F.R.C.Path., has been appointed Honorary Consultant in Pathology to the Army, with effect from 8 March 1977. He succeeds Professor B. W. Lacey, M.D., B.Sc., who has retired.

Dr. L. A. Hersov, M.D., F.R.C.P., F.R.C.Psych, D.P.M., has been appointed Honorary Consultant in Child and Adolescent Psychiatry to the Army, with effect from 15 February 1977. He succeeds Dr. W. Warren, M.A., M.D., F.R.C.P., F.R.C.Psych., D.P.M., who retired on 11 October 1975.

Professor W. W. Macdonald, D.Sc., F.I.Biol., has been appointed Honorary Consultant in Entomology to the Army, with effect from 28 March 1977. He succeeds Professor D. S. Bertram, D.Sc., F.I.Biol., who has retired.

Dr. J. W. Laws, M.B., Ch.B., F.R.C.P., C.R.C.R., has been appointed Honorary Consultant in Radiology to the Army, with effect from 7 January 1977. He succeeds Professor E. Samuel, B.Sc., M.D., F.R.C.S., F.R.C.P.(E), F.R.C.R., F.A.C.R., who has retired.

Professor P. T. Flute, T.D., M.D., M.R.C.P., F.R.C.Path., has been appointed Honorary Consultant in Haematology to the Army, with effect from 20 July 1977. He succeeds Professor Sir John V. Dacie, Kt, M.D., F.R.C.P., F.R.C.Path, who has retired.

To The Queen Elizabeth Military Hospital

Dr. H. M. Saxton, M.B., B.S., F.R.C.P., F.R.C.R., has been appointed Honorary Consultant in Radiology to the Queen Elizabeth Military Hospital, with effect from 1 April 1977. He succeeds Dr. B. Strickland, M.B., B.S., F.R.C.P., F.R.C.R., D.M.R.T. 